\title{
ACID-BASE AND ELECTROLYTE CHANGES IN INFANTS UNDERGOING PROFOUND HYPOTHERMIA FOR SURGICAL CORRECTION OF CONGENITAL HEART DEFECTS
}

\author{
A.E. Johnston, M.D., F.R.C.P.(c), I.C. RADDE, M.D., PH.D., F.R.C.P.(c), $\dagger$ \\ D.J. Steward, M.B., F.R.C.P.(c), and J. TAYLOR, B.SC."
}

\section{INTRODUCTION}

A TECHNique for producing profound hypothermia by surface cooling and rewarming to allow open-heart surgery in infants was reported by Horiuchi $e$ t al. in 1963. ${ }^{1}$ Interest has been revived recently because of the successful modifications of the technique by using bypass cooling and rewarming as described by Belsey $e t$ al. in 1968, ${ }^{2}$ and by combining initial surface cooling with subsequent bypass cooling and rewarming as described by Barratt-Boyes and his group, $1971{ }^{3,4}$ The rationale and the techniques being used for the production of profound hypothermia at The Hospital for Sick Children, Toronto, have been recently reviewed by Steward $e t a l^{5}$

We previously reported acid-base and electrolyte changes in several series of paediatric patients undergoing open-heart surgery with normo-thermic cardiopulmonary bypass. ${ }^{6-8}$ We are now reporting on a study of the acid-base and plasma electrolyte changes in infants undergoing profound hypothermia by the technique of initial surface cooling followed by further bypass cooling and rewarming. A comparison is made between the changes seen when the initial surface cooling is terminated above $30^{\circ} \mathrm{C}$ rather than being continued to $26-27^{\circ} \mathrm{C}$.

\section{Patients, Procedures and Methods}

\section{A. Patients}

These studies were carried out on 11 of the 25 cases included in the clinical review by Steward et al..$^{5}$ Table I represents data on the age and weight ranges of the patients. Seven patients (group 1) underwent initial surface cooling to a mean oesophageal temperature of $26.6^{\circ} \mathrm{C}$ and 4 (group 2) to a mean oesophageal temperature of $32^{\circ} \mathrm{C}$. In order to standardize the overall comparisons only those cases in whom fresh heparinized blood was used in the oxygenator prime were included in the complete study ( 5 cases in group 1 and 4 cases in

From the Departments of Anaesthesia ${ }^{\circ}$ and Paediatricsf, The Hospital for Sick Children, Toronto, and the University of 'Toronto.

Portions of data in this paper were presented at the Canadian Anaesthetists' Society Meeting, Vancouver, June, 1973.

Canad. Anaesth. Soc. J., vol. 21, no. 1, January 1974 
TABLE I

Patient Groups

\begin{tabular}{cccc}
\hline \hline Group & $\begin{array}{c}\text { No. of } \\
\text { Patients }\end{array}$ & $\begin{array}{c}\text { Age (Months) } \\
\text { Mean (Range) }\end{array}$ & $\begin{array}{c}\text { Weight (kg) } \\
\text { Mean (Range) }\end{array}$ \\
\hline 1 & 7 & $19.2(0.3-42)$ & $6.72(3.4-11.1)$ \\
2 & 4 & $11.0(3-24)$ & $6.45(4.0-8.3)$ \\
\hline
\end{tabular}

group 2). However, in two additional cases data only from the initial surface cooling phase were included in group 1 giving a total number of seven.

Three patients with complete studies in group 1 and two in group 2 had transposition of great vessels and underwent Mustard atrial baffle repair. The remaining two of five patients in group 1 had patch closure of the ventricular septal defect and one of these had also a right ventricular infundibulectomy. Of the remaining two patients in group 2 , one had a patch closure of an atrial septal defect, and the other a left mitral annuloplasty for mitral regurgitation.

\section{B. Procedures}

The technique of initial surface cooling, followed by bypass cooling to approximately $16^{\circ} \mathrm{C}$, circulatory arrest and bypass rewarming was as described by Steward et al..$^{5}$ As the patient's temperature was lowered to approximately $34^{\circ} \mathrm{C}$, 5 per cent $\mathrm{CO}_{2}$ was added to the inspired gas mixture to keep the temperaturecorrected $\mathrm{PCO}_{2}$ at approximately $40 \mathrm{~mm} \mathrm{Hg}$. Five per cent $\mathrm{CO}_{2}$ was added to the pump oxygenator during the periods of bypass cooling. In all seven cases of group 1 , the initial surface cooling was carried to a mean oesophageal temperature of $26.6^{\circ} \mathrm{C}$ (Table II). In the four cases of group 2, the initial surface cooling was only carried to a mean oesophageal temperature of $31.8^{\circ} \mathrm{C}$.

In the nine patients of groups 1 and 2 with complete studies, further bypass cooling resulted in a mean oesophageal temperature of $15.7^{\circ} \mathrm{C}$ prior to circulatory arrest lasting for 36 to 61 minutes (Table II). The mean duration of rewarming bypass was 18 minutes.

A Temptrol ${ }^{\circ}$ disposable bubble oxygenator was used with the haemodilution techniques previously described. ${ }^{6-8}$ The priming volume of the infant oxygenator was $800-900 \mathrm{ml}$. The volumes of diluent and blood added were calculated to produce a standard 30 per cent dilution when the priming volume and the patient's blood volume were combined at the start of bypass. The diluent used was a magnesium-containing multiple electrolyte solution (Plasma-lyte) ${ }^{\circledR}+$ with glucose added to make a 1 per cent solution. ${ }^{8}$ To each unit of fresh heparinized blood used in the prime was added $12 \mathrm{mEq} \mathrm{NaHCO}_{3}$ and $1-2 \mathrm{ml}$ of 10 per cent $\mathrm{CaCl}_{2}$.

In the post-operative period, all patients routinely received 5 per cent dextrose in 0.2 per cent $\mathrm{NaCl}$ intravenously at a rate of approximately half the calculated normal maintenance volume per day. In addition, all measured blood losses were replaced with fresh $\mathrm{ACD}$ blood. All patients received $2 \mathrm{mEq} / \mathrm{kg} / 24 \mathrm{~h}$ of $\mathrm{KCl}$

\footnotetext{
'Bentley Sales Inc., 180 Main St., Norwalk, Conn., 06851, U.S.A.

†Plasma-lyte 148 in water: $\mathrm{Na}+140 \mathrm{mEq} / \mathrm{L} ; \mathrm{K}+5 \mathrm{mEq} / \mathrm{L} ; \mathrm{Cl} 98 \mathrm{mEq} / \mathrm{L} ; \mathrm{Mg}++$ $3 \mathrm{mEq} / \mathrm{L}$; bicarbonate as acetate $27 \mathrm{mEq} / \mathrm{L}$ and as gluconate $23 \mathrm{mEq} / \mathrm{L}$. Travenol Lab. Inc., Morton Grove, Ill. 60053, U.S.A.
} 
JOHNSTON, et al: : ACDD-BASE AND ELECTROLYTE CHANGES

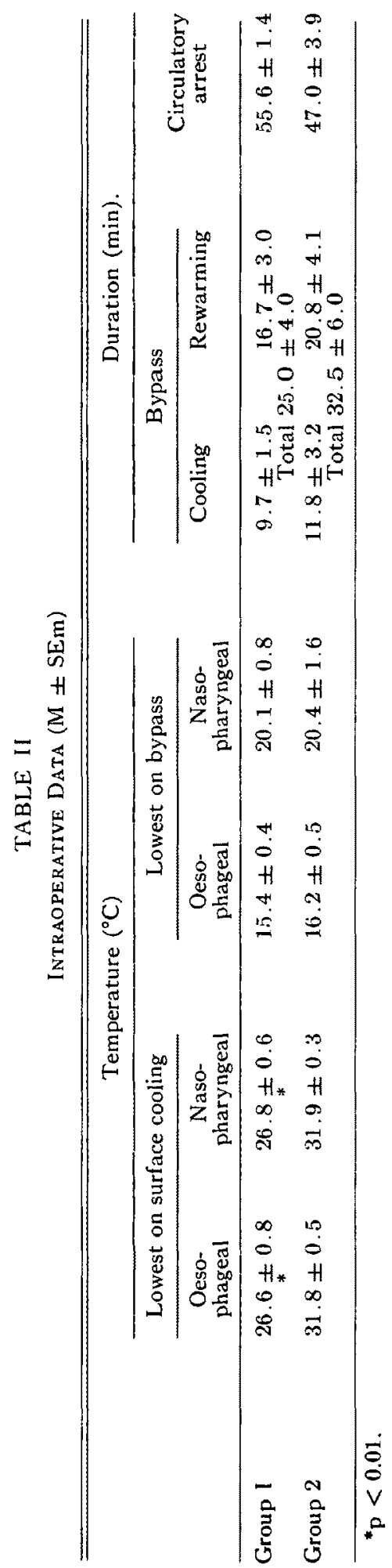


during the first 24 hours postoperatively, and patients of group 2 were given magnesium ( $1 \mathrm{mEq} / \mathrm{kg} / 24 \mathrm{~h}$ ) for the first 24 hours.

\section{Sampling}

Blood was drawn from an indwelling arterial cannula into a lightly heparinized syringe at the following times: immediately following the induction of anaesthesia (i); at the end of the period of surface cooling just before cooling bypass was begun (SC); five minutes after start of cooling bypass (C); five minutes after start of rewarming bypass $\left(W_{1}\right)$; at the end of rewarming bypass $\left(W_{2}\right)$; and after bypass during chest closure. Post-operative samples were drawn at fourhourly intervals during the first post-operative day and at eight-hourly intervals during the second post-operative day (specimens 1 to 9 ). The sample from the priming fluid was obtained from the oxygenator just before cooling bypass was begun.

Urine was collected from an indwelling catheter during the operation, at fourhourly intervals during the first post-operative day and at eight-hourly intervals during the second post-operative day.

\section{Chemical methods}

Blood, plasma and urine specimens were analyzed as follows: Arterial $\mathrm{pH}$, $\mathrm{PCO}_{2}$, and $\mathrm{Po}_{2}$ were measured immediately after the blood was drawn and warmed to $37^{\circ} \mathrm{C}$, using Radiometer microelectrodes and a PHM $27 \mathrm{pH}$ meter with gas monitor. All reported values have been corrected back to the patient's oesophageal temperature at the time of sampling using the correction factor of Rosenthal. ${ }^{9}$ The oesophageal temperature was found to be the most reliable index of the core temperature in infants. ${ }^{5}$ The haematocrit was measured by standard techniques. Sodium and potassium concentrations in plasma and urine were determined by standard flame spectrophotometric techniques ${ }^{*}$ Total calcium and magnesium concentrations in the plasma and urine were determined by emission and atomic absorption spectrophotometry, respectively. ${ }^{10,11}$ Calcium ion activity was determined on thawed frozen plasma by the method of Radde et al..$^{12}$ Blood sugar concentrations were measured by standard techniques ${ }^{13,14}$ and plasma osmolality by osmometer. $\uparrow$ The degree of haemolysis was estimated from plasma haemoglobin measurements by the method of Hunter et al. ${ }^{15}$

\section{Results}

\section{A. Arterial $\mathrm{PCO}_{2}$}

The $\mathrm{PCO}_{2}$ values (mean $\pm \mathrm{SEM}$ ) are shown in Figure 1. At induction of anaesthesia, values were normal in both groups. During the period of surface cooling by the addition of 5 per cent $\mathrm{CO}_{2}$ to the inspired gas mixture, the mean $\mathrm{PCO}_{2}$ was maintained close to $40 \mathrm{~mm} \mathrm{Hg}$ although there was a wide scatter of individual values. Despite the addition of 5 per cent $\mathrm{CO}_{2}$ during bypass cooling the mean $\mathrm{PCO}_{2}$ values decreased significantly and varied between 18 and $26 \mathrm{~mm}$

-IL Flame Spectrophotometer, model 143.

†Model 3-L Osmometer, Advanced Instruments, Inc., Newton Highlands, Mass., U.S.A. 


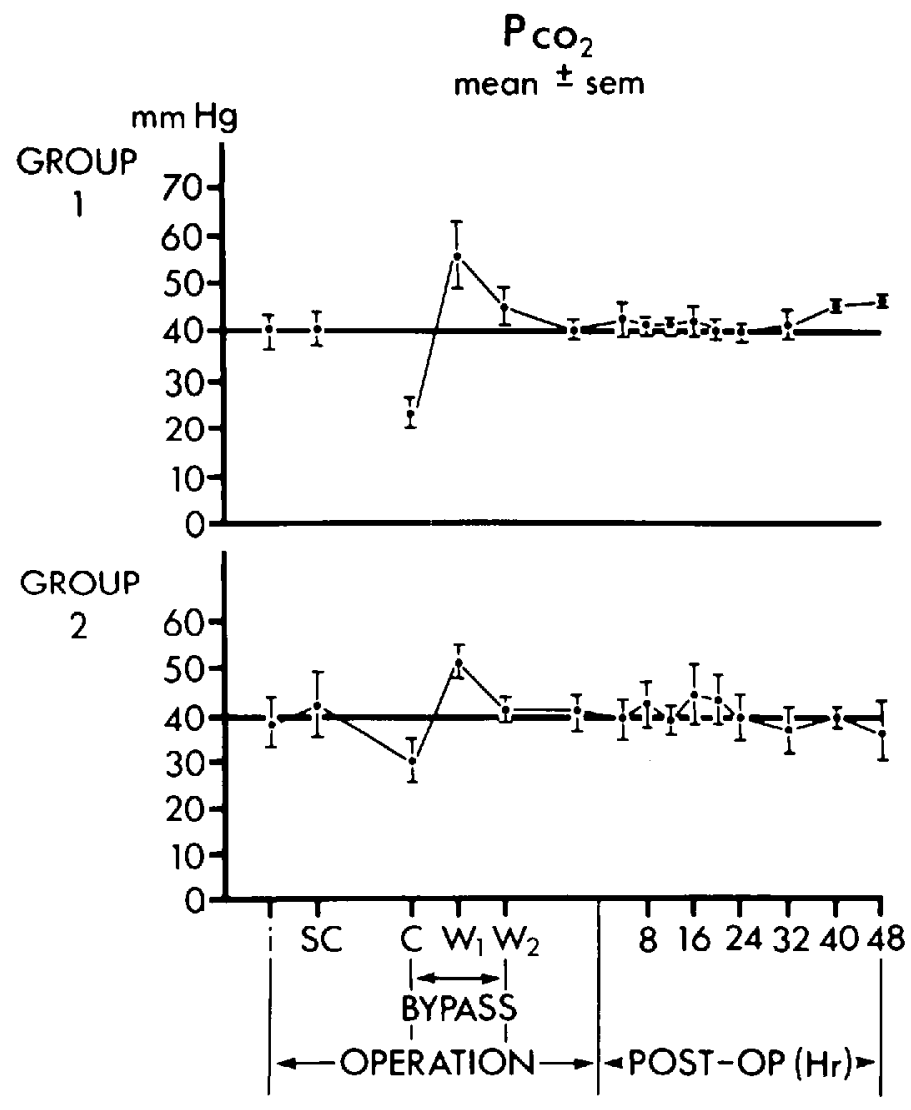

Figure 1. Arterial blood $\mathrm{PCO}_{2}\left(\mathrm{PaCO}_{2}\right)$ (mean $\left.\pm \mathrm{SEm}\right)$. $\mathrm{i}=$ specimen taken at induction; $\mathrm{SC}=$ specimen taken at the end of the period of surface cooling; $\mathrm{C}=$ specimen taken $5 \mathrm{~min}$ after start of cooling bypass; $W_{1}$ and $W_{2}=$ specimens taken 5 min after and at the end of warming bypass, respectively.

$\mathrm{Hg}$ in group 1 and between 22 and 41 in group 2. Early during bypass-rewarming the $\mathrm{PCO}_{2}$ rose but later gradually declined to nearly normal values by the end of bypass. The values remained within the normal range during the post-bypass and post-operative period whether ventilation was spontaneous or assisted.

\section{B. $p H$ and Base Deficit}

The mean arterial blood $\mathrm{pH}$ at induction was slightly lower in group 1 than in group 2 (Figure 2). Although there was a trend to a slight decrease in $\mathrm{pH}$ during the period of surface cooling, values did not change significantly. Similarly, there was a slight, though not significant, increase in the mean calculated negative base excess values during surface cooling in both groups. Nevertheless, four patients did develop metabolic acidosis of a degree requiring treatment. The acidosis occurred during periods of hypotension resulting from cardiac manipulation and cannulation immediately prior to the start of bypass cooling.

During bypass cooling, the $\mathrm{pH}$ rose in both groups but only in group 2 was the rise statistically significant $(\mathrm{p}<0.01)$. As the slight decrease in the calcu- 


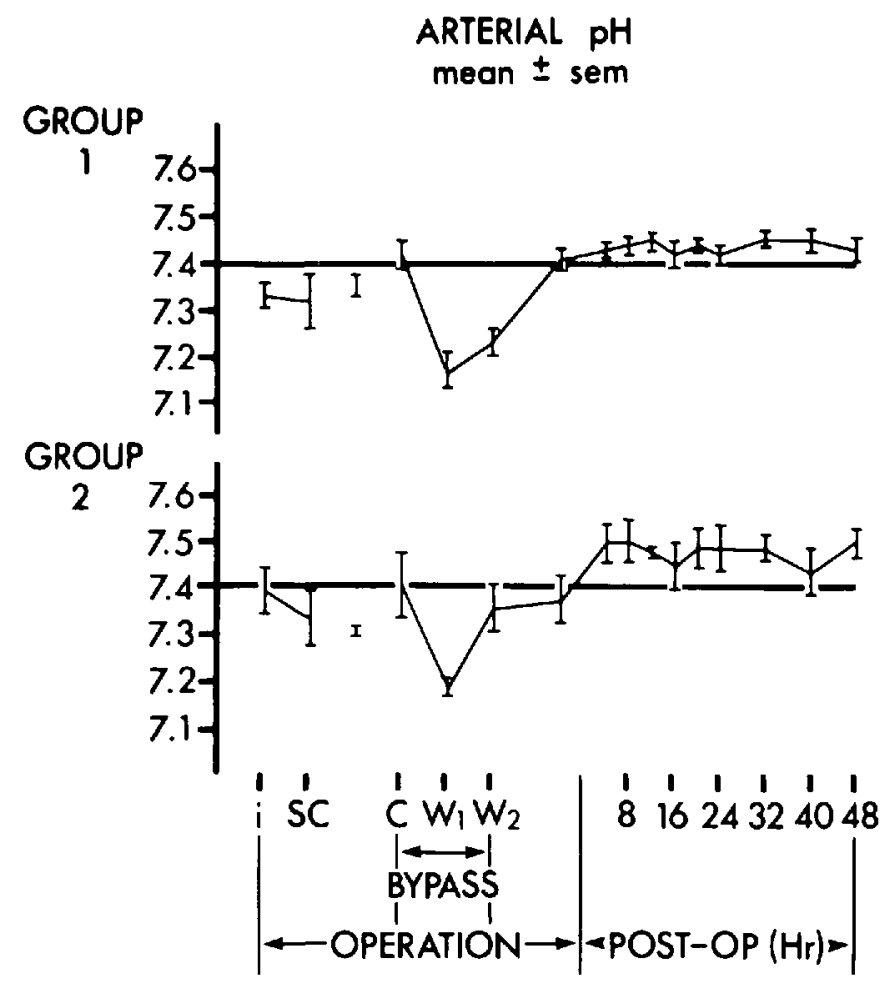

Figure 2. Arterial blood pH (mean $\pm \mathrm{SEm}$ ). $\mathrm{i}=$ specimen taken at induction; $\mathrm{SC}=$ specimen taken at the end of the period of surface cooling; $\mathrm{C}=$ specimen taken 5 min after start of cooling bypass; $W_{1}$ and $W_{2}=$ specimens taken 5 min after and at the end of warming bypass, respectively.

lated negative base excess was insignificant in both groups, the rise in $\mathrm{pH}$ was primarily the result of the lowered $\mathrm{PCO}_{2}$ values during this period.

Between the bypass cooling-sample and the first sample during rewarming, encompassing the period of circulatory arrest, the arterial blood $\mathrm{pH}$ decreased significantly to mean values of 7.16 (group 1 ) and 7.18 (group 2). This marked $\mathrm{pH}$ change reflects an alteration in both the metabolic and respiratory components. The rise in $\mathrm{PcO}_{2}$ and the increased negative base excess values were both significant $(\mathrm{p}<0.01)$. During bypass-rewarming the $\mathrm{pH}$ increased towards normal, reflecting both a decrease in $\mathrm{PCO}_{2}$ and the partial correction of the metabolic component. At chest closure, mean $\mathrm{pH}$ values had returned to the normal range.

Post-operatively, the mean $\mathrm{pH}$ values rose to between 7.45 and 7.50 in both groups with calculated mean base excess values between +4 and +8 . The postoperative metabolic alkalosis in both groups reflects the fact that sodium bicarbonate was administered in an attempt to correct the metabolic acidosis during bypass rewarming in all but three of the cases.

In Figure 3 the $\mathrm{pH}$ in two individual cases is contrasted. Case 53 was given sodium bicarbonate during bypass rewarming and the $\mathrm{pH}$ continued to rise to a range around 7.5 post-operatively. Case 55 did not receive sodium bicarbonate, 
ARTERIAL $\mathrm{pH}$

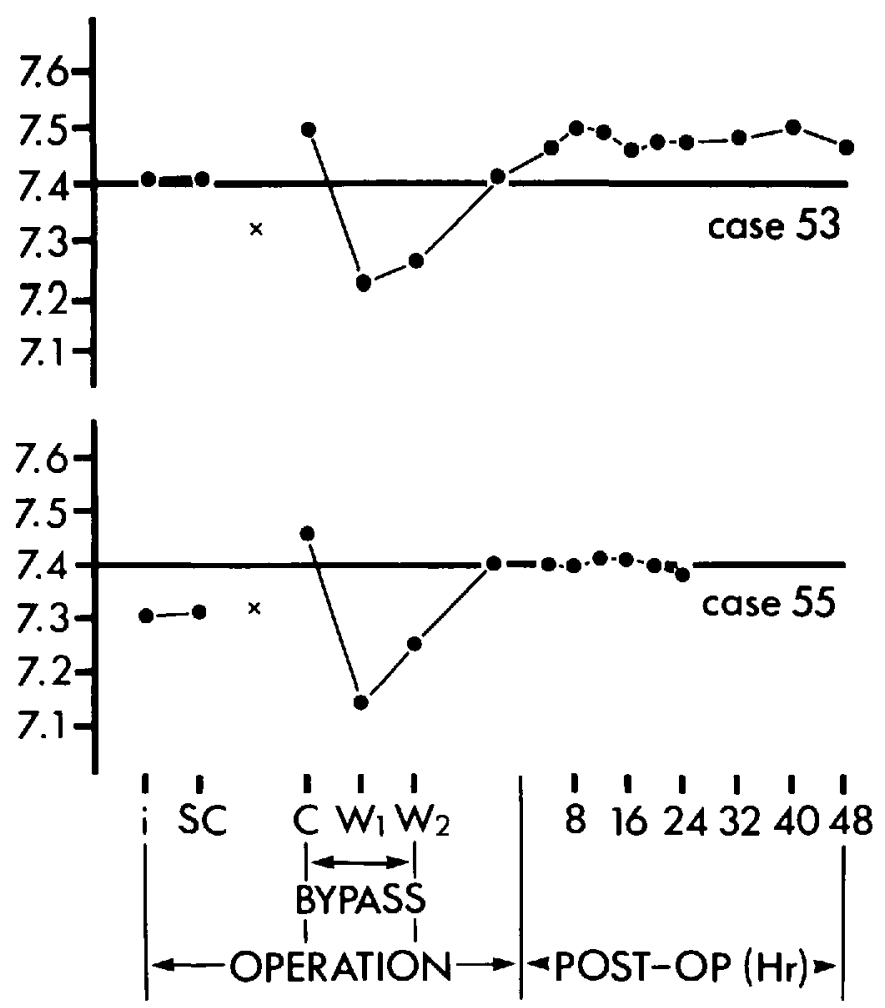

Figure 3. Arterial blood $\mathrm{pH}$ of two individual patients. $\mathrm{x}=$ value in priming solution; $\mathrm{i}=$ specimen taken at induction; SC = specimen taken at the end of the period of surface cooling; $\mathbf{C}=$ specimen taken $5 \mathrm{~min}$ after start of cooling bypass; $W_{1}$ and $W_{2}=$ specimens taken $5 \mathrm{~min}$ after and at the end of warming bypass, respectively.

but the $\mathrm{pH}$ also began to rise during bypass rewarming and continued to do so following bypass, reaching a value of 7.4 at chest closure. The normal acid-base status in Case 55 was maintained during the post-operative period.

\section{Plasma Potassium}

At induction of anaesthesia, plasma potassium values were within the normal range in both groups. During surface cooling a highly significant decrease in plasma potassium concentration was seen in the patients of group 1 , ranging between 0.8 and $2.2 \mathrm{mEq} / 1$ and all values in patients of this group became subnormal (Figure 4). In patients of group 2, the decrease in plasma potassium concentration was less and not statistically significant, although in three out of four patients, the decrease ranged from 0.2 to $1.0 \mathrm{mEq} / 1$ with a mean of 0.7 $\mathrm{mEq} / 1$. The difference between the groups was highly significant $(\mathrm{p}<0.01)$. No statistical correlation was found between the degree of potassium change and that of plasma $\mathrm{pH}$ or $\mathrm{PCO}_{2}$.

During surface cooling ventricular fibrillation occurred in two patients of group 

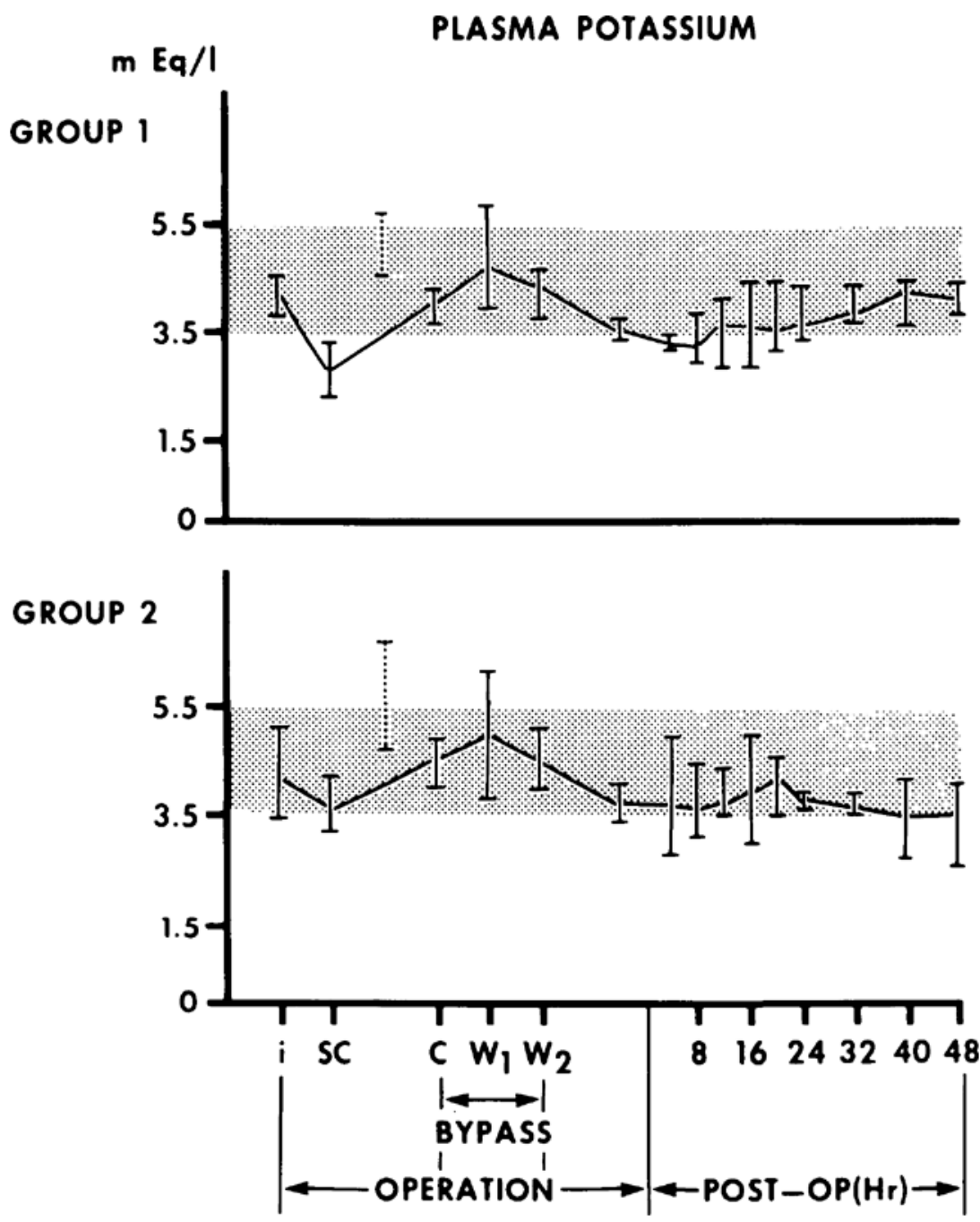

Figure 4. Plasma potassium concentrations (mean and range). Shaded areas indicate the normal range. Interrupted bar $=$ range of values in priming solution; $i=$ specimen taken at induction; $\mathrm{SC}=$ specimen taken at the end of the period of surface cooling; $\mathrm{C}=$ specimen taken 5 min after start of cooling bypass; $W_{1}$ and $W_{2}=$ specimens taken 5 min after and at the end of warming bypass, respectively.

1 , both having been digitalized pre-operatively. However, four other patients in group 1 and three in group 2 had been digitalized and ventricular fibrillation did not occur. The two infants in whom ventricular fibrillation occurred had the greatest decrease of 1.4 and $2.2 \mathrm{mEq} / 1$ of plasma $\mathrm{K}^{+}$during surface cooling and were the two cases in whom the lowest values were recorded $(2.3$ and $2.7 \mathrm{mEq} / 1$, respectively). No common acid-base abnormality was noted between the two patients in whom ventricular fibrillation occurred during the initial surface cooling.

Despite the decrease in plasma $\mathrm{K}^{+}$during surface cooling, values returned to normal in both groups during bypass cooling due to the high normal potassium 
m Eq/I

PLASMA SODIUM
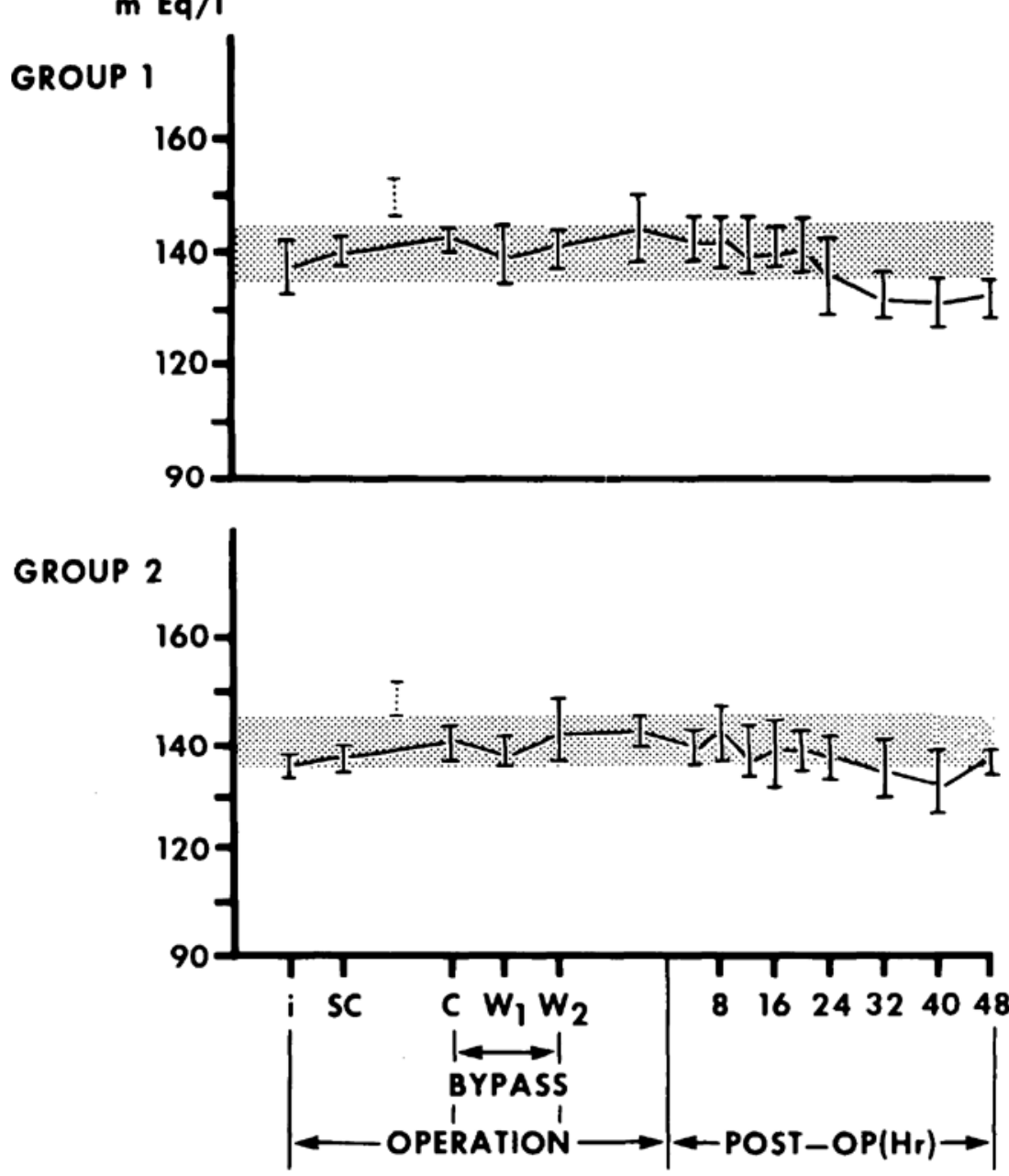

Frgure 5. Plasma sodium concentrations (mean and range). Shaded areas indicate the normal range. Interrupted bar $=$ range of values in priming solution; $\mathbf{i}=$ specimen taken at induction; $\mathrm{SC}=$ specimen taken at the end of the period of surface cooling; $\mathrm{C}=$ specimen taken 5 min after start of cooling bypass; $W_{1}$ and $W_{2}=$ specimens taken 5 min after and at the end of warming bypass, respectively.

content in the priming solution (Figure 4). During bypass rewarming potassium values began to decrease and reached the low normal range by chest closure.

Plasma $\mathrm{K}^{+}$values remained low in patients of both groups during the first 24 post-operative hours. Half the values were in the hypokalaemic range despite the routine administration of potassium in the dosage of $2 \mathrm{mEq} / \mathrm{kg} / 24 \mathrm{~h}$.

\section{Plasma $\mathrm{Na}^{+}$}

Plasma $\mathrm{Na}^{+}$values were normal in both groups at induction and no change occurred during surface cooling (Figure 5). During bypass cooling, plasma $\mathrm{Na}+$ rose slightly, reflecting the higher sodium concentration in the priming solution. 

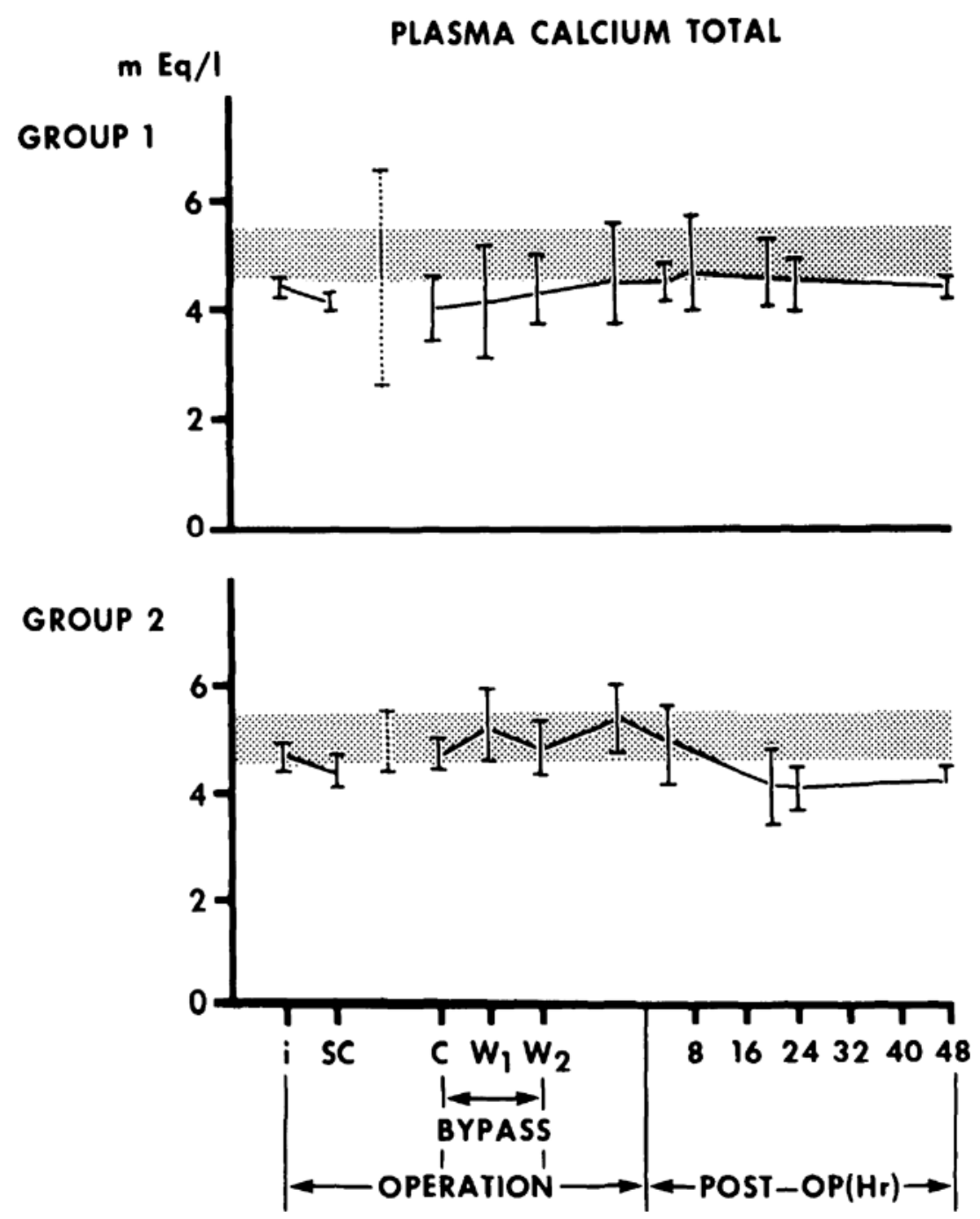

Figure 6. Total calcium concentrations in plasma (mean and range). Shaded areas indicate the normal range. Interrupted bar $=$ range of values in priming solution; $i=$ specimen taken at induction; $\mathrm{SC}=$ specimen taken at the end of the period of surface cooling; $\mathrm{C}=$ specimen taken 5 min after start of cooling bypass; $W_{1}$ and $W_{2}=$ specimens taken 5 min after and at the end of warming bypass, respectively.

This increase was not statistically significant. Normal plasma sodium values were maintained throughout operation and the early post-operative period. Mild hyponatraemia developed in both groups on the second post-operative day.

\section{E. Calcium (Total and Ionic)}

Although total calcium levels were low in most patients in both groups at induction, ionic calcium was in the normal range for the patients' age (Figures 6 and 7). Similarly, there was a tendency to a further decrease of total calcium concentrations during surface cooling, particularly in group 1 , but the changes 

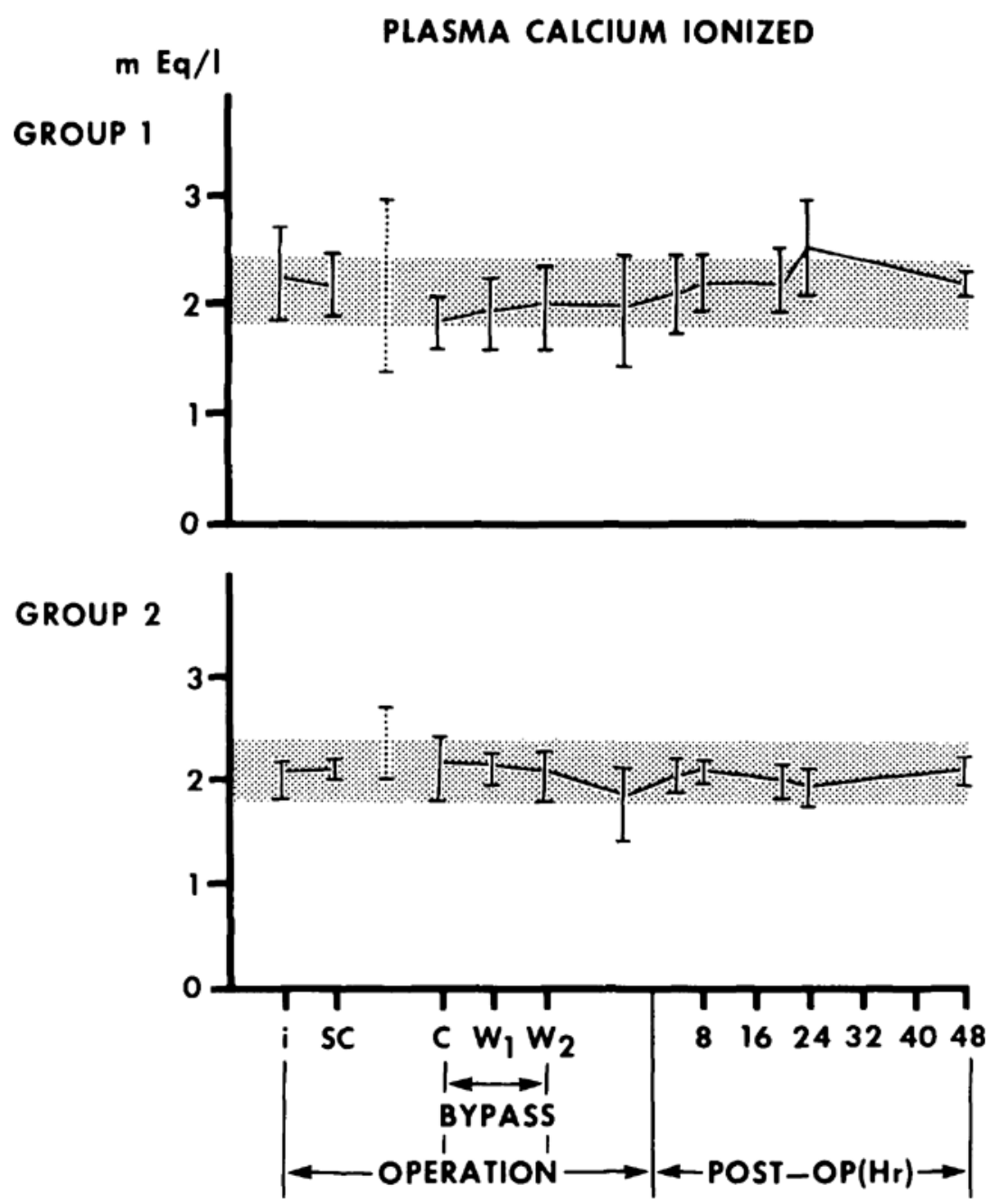

Figure 7. Ionized calcium concentrations (mean and range). Shaded areas indicate the normal range. Interrupted bar $=$ range of values in priming solution; $i=$ specimen taken at induction; $\mathrm{SC}=$ specimen taken at the end of the period of surface cooling; $\mathbf{C}=$ specimen taken 5 min after start of cooling bypass; $W_{1}$ and $W_{2}=$ specimens taken 5 min after and at the end of warming bypass, respectively.

were not statistically significant. Furthermore, ionic calcium remained unchanged and entirely within the normal range during surface cooling.

The wide variation of both total calcium and ionic calcium concentrations in the priming solutions resulted from the different amounts of $\mathrm{CaCl}_{2}$ added. Initially, only $1.0 \mathrm{ml}$ of 10 per cent $\mathrm{CaCl}_{2}$ was added to each unit of heparinized blood (four or five cases of group 1) but this was increased in the remaining cases to $2.0 \mathrm{ml}$. The lower values of total and ionized calcium during bypass cooling and rewarming in group 1 confirm the necessity of adding $2.0 \mathrm{ml}$ of $\mathrm{CaCl}_{2}$ per unit of blood. In spite of the low total calcium concentrations in the plasma 


\section{m Eq/I}

\section{PLASMA MAGNESIUM TOTAL}
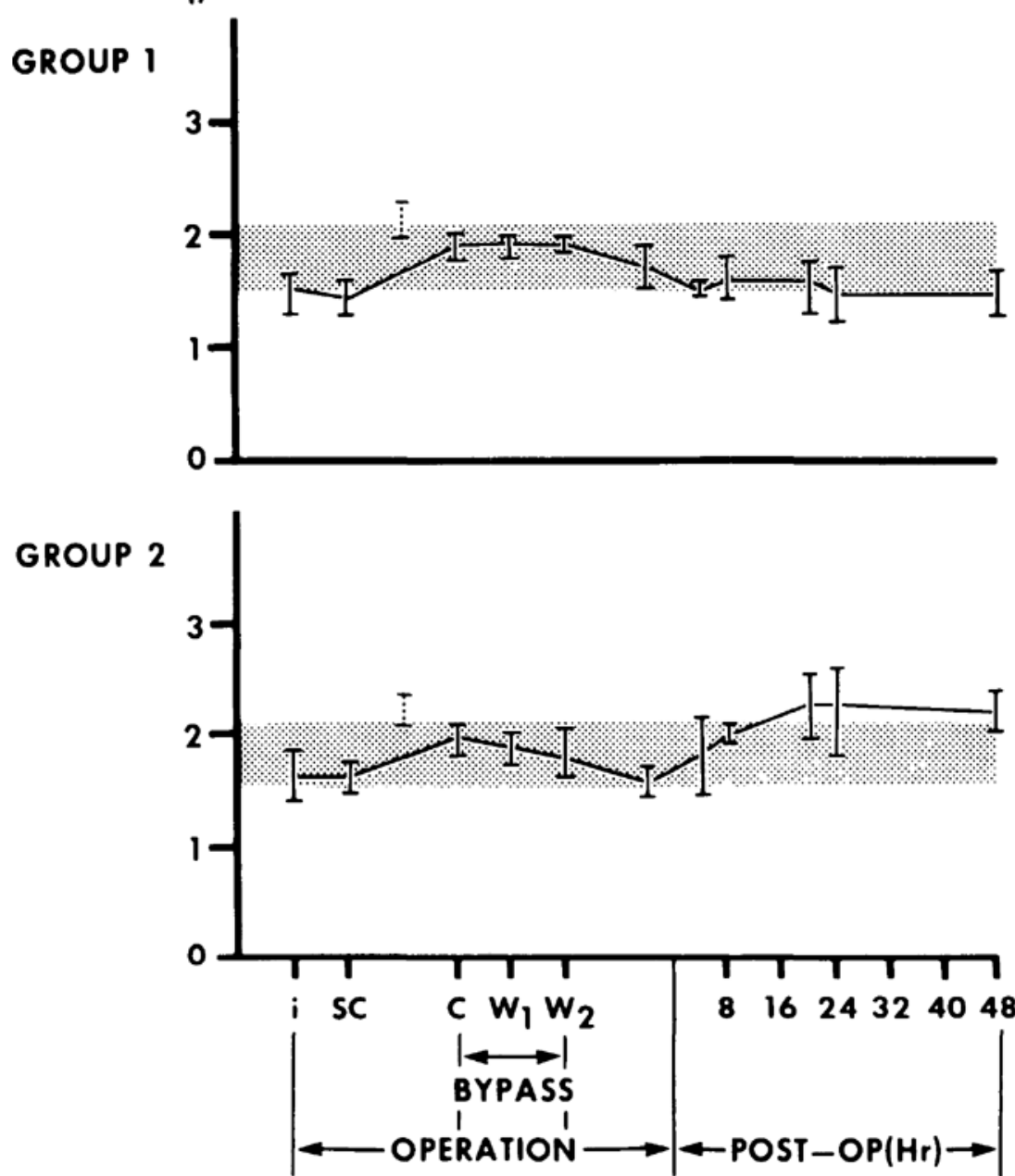

Figure 8. Total magnesium concentrations (mean and range). Shaded areas indicate the normal range. Interrupted bar $=$ range of values in priming solution; $i=$ specimen taken at induction; $\mathrm{SC}=$ specimen taken at the end of the period of surface cooling; $\mathrm{C}=$ specimen taken 5 min after start of cooling bypass; $W_{1}$ and $W_{2}=$ specimens taken $5 \mathrm{~min}$ after and at the end of warming bypass, respectively.

of patients in both groups during the post-operative period, ionized calcium levels were well maintained during this time.

\section{G. Plasma Magnesium}

Total magnesium concentrations in plasma at induction were in the low-normal range and did not change during surface cooling. Magnesium concentrations increased and were maintained in the normal range during bypass in both groups, as a result of the high normal concentration in the priming solution (Figure 8).

Because of the post-operative administration of magnesium to patients in group 2, plasma magnesium concentrations became significantly higher in this group 
than in those of group 1 . The value remained at the upper limit of normal or slightly above, whereas three out of four patients of group 1 developed mild hypomagnesaemia.

\section{H. Protein, sugar, osmolality, haematocrit and degree of haemolysis}

The osmolality showed the expected increase during bypass cooling and rewarming, reflecting the moderately high values in the priming fluid (Table III). Osmolality gradually decreased during the post-operative period. Forty-eight hours post-operatively the values for patients in group 2 were slightly increased, whereas the values for patients in group 1 were significantly lower than normal and the mean values for both differed significantly.

The degree of haemolysis was not different between groups during surface cooling, bypass cooling and rewarming (Table III). It reflected the degree of haemolysis in the priming fluid.

The haematocrit in the bypass cooling sample was close to the anticipated range of 25 per cent to 30 per cent. Values gradually rose to means of about 40 per cent during the early post-operative period.

Blood sugar and plasma protein values did not differ between groups 1 and 2. Blood sugar increased significantly during surface cooling, and again at the initiation of bypass. The levels were gradually decreasing but mean values were still above $250 \mathrm{mg}$ per $100 \mathrm{ml}$ at the time of chest closure.

\section{Urinary Flow and Cation Excretion}

Urinary flow rates and electrolyte excretion rates were similar between the two groups during the operative period (Table IV). Post-operatively, flow rates varied widely but mean values were similar between groups. Large variations were also seen in the post-operative sodium and potassium excretion rates.

Because the patients in group 2 received magnesium supplements their postoperative magnesium excretion was higher than group 1 during the first and second post-operative day. Calcium excretion also differed between groups and was higher in group 2 than in group 1 between four and forty-eight hours postoperatively.

\section{Discussion}

The changes in $\mathrm{PCO}_{2}$ and other acid-base parameters which occur during hypothermia have been extensively reviewed in the literature. ${ }^{16-22}$ Carbon dioxide becomes more soluble and the protein anion concentration decreases in body fluids. ${ }^{16}$ The relationship between total $\mathrm{CO}_{2}, \mathrm{PCO}_{2}$, and $\mathrm{pH}$ as expressed by the Henderson-Hasselbalch equation is disturbed, as it is dependent on a constant, the $\mathrm{pK}$, which increases by 0.005 unit with each degree centigrade decrease in temperature. This change in $\mathrm{pK}$ more than offsets the acidotic effect of the increase in dissolved $\mathrm{CO}_{2}$ during hyopthermia. Thus, in vitro, the $\mathrm{pH}$ rises linearly as the temperature falls.

In vivo, during surface cooling, respiratory acidosis develops unless ventilation is assisted or controlled. ${ }^{16}$ However, with controlled ventilation in the anaesthe- 


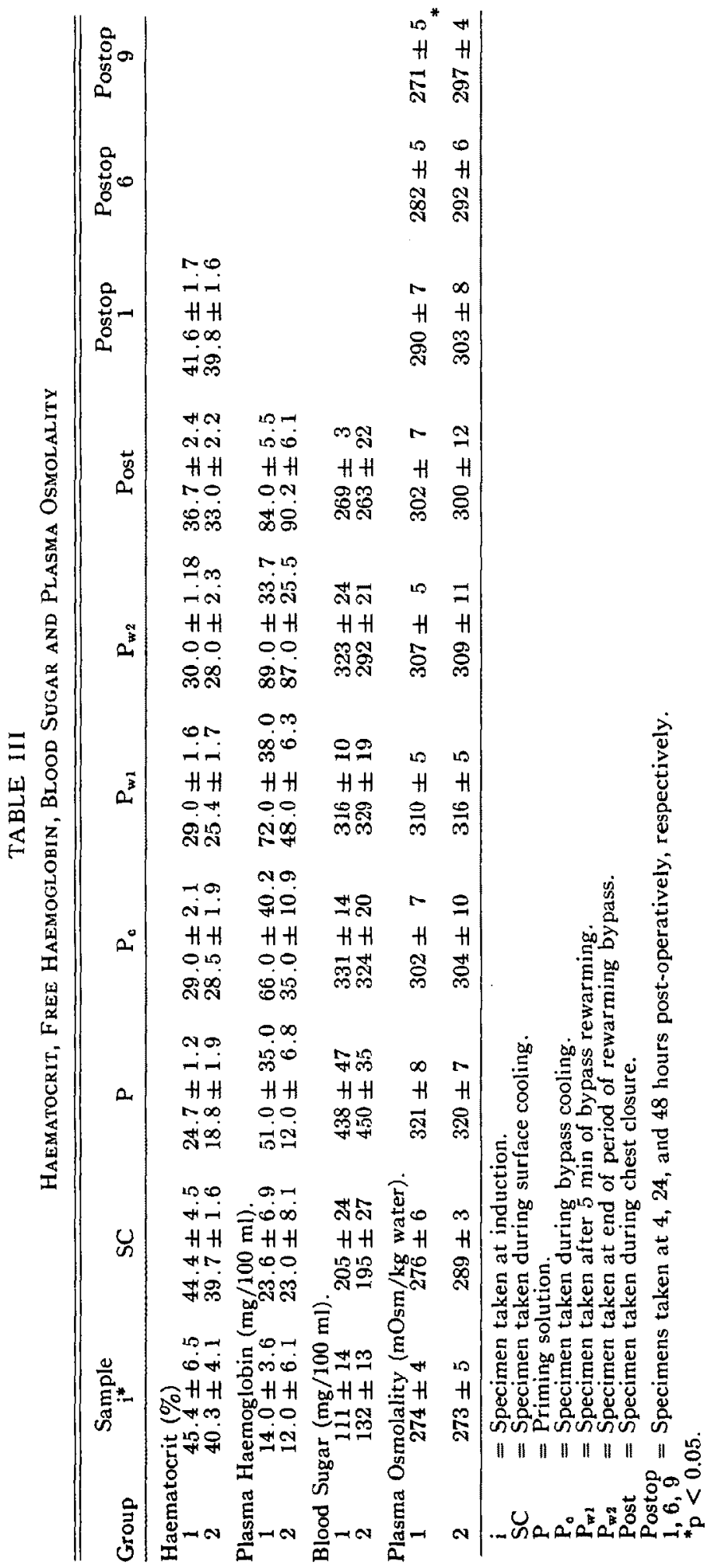




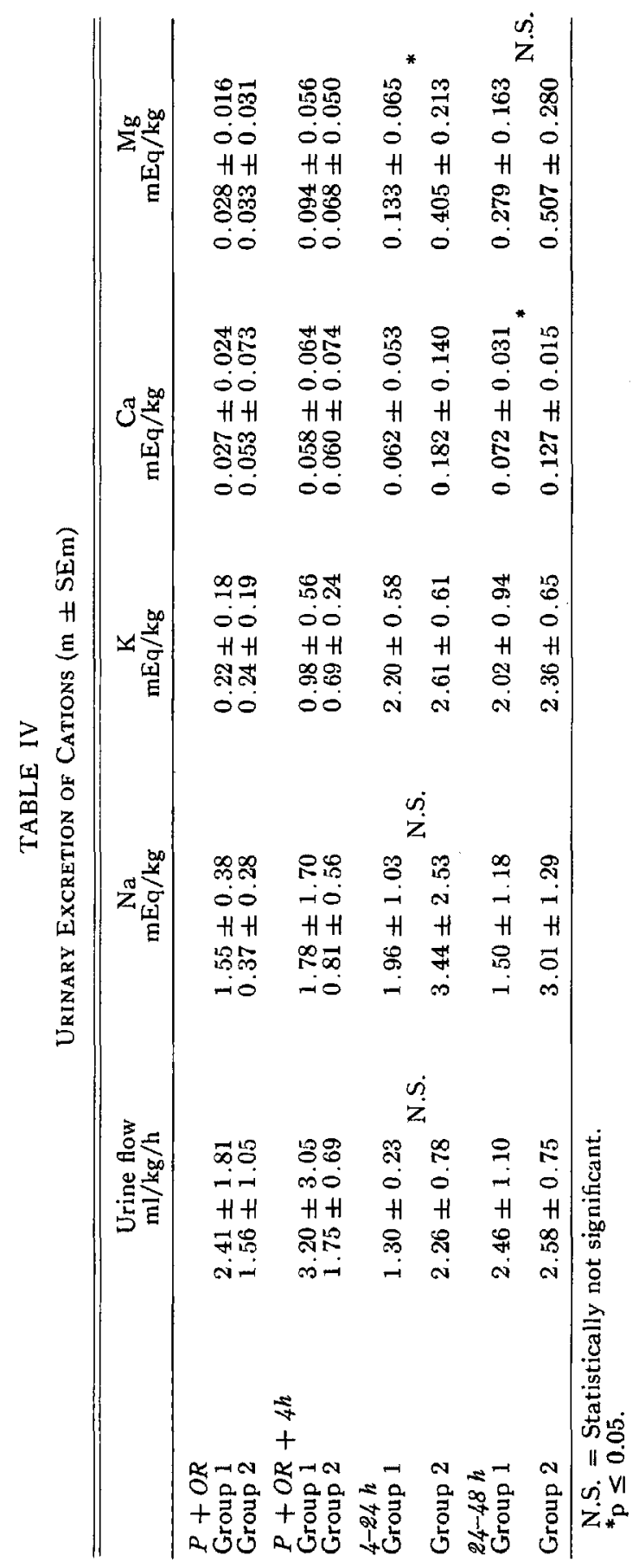


tized hypothermic patient, the $\mathrm{PCO}_{2}$ will fall precipitously if the minute volume is maintained at a level normal for normothermia. ${ }^{21}$ At all body temperatures the $\mathrm{PaCO}_{2}$ should probably be maintained close to $40 \mathrm{~mm} \mathrm{Hg}$ by the addition of $\mathrm{CO}_{2}$ in the inspired gas mixture to prevent both cerebral vasoconstriction and the shift of the $\mathrm{O}_{2}$ dissociation curve far to the left which occurs when a low $\mathrm{PcO}_{2}$ and hypothermia are combined. ${ }^{21,22}$ Thus sufficient oxygen should be available to meet the reduced $\mathrm{O}_{2}$ requirements. Normal or increased $\mathrm{PCO}_{2}$ levels combined with the effects of general anaesthesia should minimize the peripheral vasoconstriction which occurs during cooling, and this also should improve peripheral perfusion and help to reduce uneven cooling between body compartments. This will keep to a minimum the production of acid metabolites, an almost inevitable accompaniment of clinical hypothermia. ${ }^{16}$

We found that the $\mathrm{pH}$ and calculated base excess values did not change significantly during the period of surface cooling unless there had been an episode of hypotension during cannulation before bypass. This would agree with in vitro studies in which hypothermia produced only slight $\mathrm{pH}$ changes in the blood if $\mathrm{CO}_{2}$ was added to maintain $\mathrm{PcO}_{2}$ of $40 \mathrm{~mm} \mathrm{Hg}{ }^{21}$

The acid-base values reported during bypass cooling are obviously strongly affected by the composition of the oxygenator-prime so that changes which might have been expected purely on the basis of the further rapid cooling to $16^{\circ} \mathrm{C}$ have been modified. The addition of 5 per cent $\mathrm{CO}_{2}$ to the oxygenator was insufficient to maintain normal $\mathrm{PCO}_{2}$ values in our patients during the rapid blood stream cooling. At least 10 per cent $\mathrm{CO}_{2}$ is probably necessary during this period. The increases in $\mathrm{pH}$, which we observed during cooling bypass, reflect the lower $\mathrm{PCO}_{2}$ levels which were not associated with any significant degree of metabolic acidosis as indicated by the calculated negative base excess values.

Belsey et al. have reported the development of metabolic acidosis during bypass cooling. ${ }^{2}$ This was attributed to the effects of ACD blood in the prime. In our series, blood losses during the surface cooling phase were replaced by fresh frozen plasma; buffered fresh heparinized blood was used in the prime and for any replacement required during bypass. Seelye et al. ${ }^{4}$ using a buffered heparinized blood priming solution, have reported an unexplained "alkaline shift" during bypass cooling not wholly accounted for by the addition of bicarbonate or changes in lactic acid levels. We are unable to comment on this "unexplained shift" since we did not measure lactic acid levels.

The occurrence of significant metabolic acidosis, which we observed early during bypass rewarming, has been well documented as being associated with increased levels of lactic acid released following the period of bypass cooling and circulatory arrest.,4,20 During rewarming, we also observed a progressive rise in $\mathrm{pH}$ associated with a reduction in the metabolic component as reflected by a decrease in the calculated negative base excess values. Again, we are unable to comment on the unexplained "acid shift" during bypass rewarming reported by Seelye et al."

Early in our series, we attempted to correct metabolic acidosis during rewarming by the administration of sodium bicarbonate. With more experience, we added less and less sodium bicarbonate because the patients were developing 
post-operative metabolic alkalosis. It became apparent that with restoration of circulation and rewarming, spontaneous correction of the acidosis occurred. If myocardial contractility was adequate to maintain blood pressure and peripheral perfusion, post-bypass, this spontaneous correction of acidosis continued. Probably the restoration of circulation through the rewarmed liver is of particular importance.

In three patients studied later in this series who did not receive sodium bicarbonate during rewarming we observed a $\mathrm{pH}$ close to 7.4 with base excess values of 0 to -3 at chest closure. This normal acid base state was maintained during the post-operative period in these three patients. With this experience we now agree with the statement by Belsey that "it is inadvisable to attempt to correct the metabolic acidosis during the rewarming phase, since it only leads to unnecessary metabolic alkalosis." 2

We have previously reported on the changes in plasma cation levels in children undergoing normothermic cardiopulmonary bypass using the same haemodilution technique., ${ }^{4,5,6}$ In the present study changes occurring pre-bypass resulted primarily from the effect of surface cooling. During bypass cooling any potential changes which might have resulted from the further rapid drop in temperature were modified or overshadowed by the effect of the cation concentrations in the priming solution.

Reports in the literature on the effect of hypothermia on plasma potassium levels are confusing, due mainly to the variations in cooling and rewarming techniques and whether shivering occurred, or not. In earlier reports ${ }^{18,19}$ as well as in a recent textbook of anaesthesia, ${ }^{23}$ the plasma $\mathrm{K}^{+}$concentration was said to rise during surface cooling; but in more recent studies hypokalemia has been reported..$^{20,24-27}$ We also found a highly significant decline in plasma $\mathrm{K}^{+}$levels when surface cooling was carried down to $26^{\circ}$ to $27^{\circ} \mathrm{C}$.

The mechanism producing the decline in plasma $\mathrm{K}^{+}$is not fully understood. It seems clear now that it is not dependent primarily on changes of blood $\mathrm{pH}$ or $\mathrm{PCO}_{2}$ or to a net loss of body potassium and that the change is reversible on rewarming. ${ }^{20,27}$

During hypothermia inhibition of the cellular cation pump resulting in the movement of electrolytes down concentration gradients and reduction in cellular uptake and metabolism of glucose have been reported. ${ }^{28,29}$ However, both these effects should cause hyper- rather than hypokalaemia. More recent reports indicate a possible relationship between hypokalaemia, low plasma insulin levels, and the abolition of the insulin response to a glucose load during hypothermia. ${ }^{25,30-32}$

The exact nature of the adrenal cortical and medullary responses to hypothermia and their influence on plasma potassium levels have not yet been clarified. ${ }^{23,38-36}$ However, there seems little doubt that adrenal secretory changes may be the predominant mechanism since Munday demonstrated as early as 1958 that hypothermic hypokalaemia did not occur in adrenalectomized animals. ${ }^{27}$

Although the evidence is certainly not conclusive in a small series of patients such as ours, we have been impressed by an apparent relationship between the degree of hypokalaemia developed during surface cooling and the occurrence of ventricular fibrillation. The two cases in which ventricular fibrillation occurred 
had been digitalized and were those having the greatest change in potassium and the lowest potassium concentrations.

It has been recommended that potassium be administered during the surface cooling phase to manage cardiac arrhythmias. ${ }^{25}$ In our experience, the onset of ventricular fibrillation has been sudden, without preceding arrhythmias and, as reported by Steward et al., other arrhythmias, when they did occur, have not been a problem in management and were not followed by ventricular fibrillation. ${ }^{5}$ Because of the possible relationship between hypothermic hypokalaemia and ventricular fibrillation, we now initiate bypass cooling before the temperature reaches $30^{\circ} \mathrm{C}$, especially in patients who are digitalized.

We observed a slight decrease in plasma $\mathrm{K}^{+}$during bypass rewarming but subnormal values were not reached until chest closure. Potassium levels remained low during the first 24 hours postoperatively, despite routine administration of potassium in a dose of $2 \mathrm{mEq} / \mathrm{kg} / 24 \mathrm{~h}$. Thus the dose should be increased to $3-4 \mathrm{mEq} / \mathrm{kg} / 24 \mathrm{~h}$ depending on renal function and plasma $\mathrm{K}^{+}$concentrations.

Increases in plasma total calcium have been reported by Dundee and Clark ${ }^{18}$ and by Little ${ }^{19}$ during surface cooling, while more recent reports indicate either no change ${ }^{37}$ or a slight decrease of this cation. ${ }^{25}$ In our series we found no change in the physiologically active plasma fraction, ionized calcium, even though there was a slight but not significant decrease in total calcium during surface cooling.

When ionic calcium is maintained in the normal range during bypass by suitable addition of $\mathrm{CaCl}_{2}$ to the priming solutions, as in the present series, the chances of postoperative ionic hypocalcaemia are considerably lessened. This is shown by a comparison with our first reported series of patients with normothermic cardiopulmonary bypass using heparinized blood without the addition of calcium. ${ }^{6}$ The post-operative administration of calcium salts to correct total hypocalcaemia (Figure 6) may even be clinically inappropriate, as a result elevation of ionic calcium levels in the presence of hypokalaemia might be deleterious.

Although a correction factor is necessary when $\mathrm{pH}$ is measured at $37^{\circ}$ in blood taken from hypothermic patients, ${ }^{9}$ it has been shown that albumin-binding of calcium and thus the $\mathrm{Ca}^{2+} /$ total $\mathrm{Ca}$ ratio is completely temperature-independent ${ }^{38}$ and thus no correction factor is necessary.

The reported changes in plasma magnesium concentrations during surface cooling are also inconsistent. Hypothermic hypermagnesaemia has been observed in experimental animals ${ }^{39,40}$ This finding could be attributed to a decrease in glomerular filtration rate ${ }^{41}$ or to cessation of active and a smaller decrease in passive magnesium fluxes. ${ }^{29}$ However, we did not observe such changes during surface cooling. Plasma magnesium concentrations during bypass cooling and rewarming were similar to those we observed in an earlier series of patients. ${ }^{8}$

Postoperatively, magnesium levels were at the lower limit of normal or slightly subnormal. Following the observation of hypomagnesaemia in association with neurological problems in one patient, not included in the present study, ${ }^{5}$ the routine post-operative administration of magnesium $(1 \mathrm{mEq} / \mathrm{kg} / 24 \mathrm{~h}$ for 1 day) was initiated in all patients in group 2. This therapy led to increased plasma levels and urinary excretion of magnesium. Since renal reabsorption of magnesium and calcium occurs through a common mechanism, ${ }^{42,43}$ the higher urinary mag- 
nesium excretion rates were probably responsible for the higher urinary calcium excretion in group 2 compared to group 1. The lower total calcium concentrations in plasma in group 2 during the end of the first and the second post-operative day may have been a consequence of the greater urinary losses of calcium.

We have no explanation for the somewhat decreased plasma magnesium and total calcium concentrations in the induction specimens. Although diuretic therapy was used in some of the infants studied in the present series, the mean plasma potassium concentrations were not low and total calcium and magnesium should not have been affected. Our normal values for plasma total calcium in infants ( $0-3$ years of age) are in the same range as those of older children and adults (unpublished observations). Although Putman ${ }^{44}$ reported high ionic calcium concentrations in a group of older children with chronic heart disease, this was not the finding in the infants investigated in this study.

\section{Conclusions and Recommendations}

The technique of profound hypothermia would appear to have a place in treating a selected group of infants requiring corrective cardiac surgery at a very young age. As a result of the present study we suggest the following modifications of our reported technique: ${ }^{5}$

1. Because of significant decreases in plasma potassium concentration in group 1 during the initial surface cooling and the possible relationship to ventricular fibrillation in digitalized patients, we recommend that bypass cooling should be initiated before the oesophageal temperature reaches $30^{\circ} \mathrm{C}$.

2. The addition of $2.0 \mathrm{ml}$ of 10 per cent $\mathrm{CaCl}_{2}$ per unit of heparinized blood used in the oxygenator prime or as replacement during bypass, is required to maintain normal calcium ion activity.

3. At least 10 per cent $\mathrm{CO}_{2}$ is required to maintain $\mathrm{PaCO}_{2}$ of $40 \mathrm{~mm} \mathrm{Hg}$ during cooling bypass.

4. The addition of $\mathrm{NaHCO}_{3}$ to correct the metabolic acidosis during bypass rewarming is usually unnecessary as it will result in post-operative metabolic alkalosis.

5. The post-operative dosage of potassium in these infants should be increased to $3-4 \mathrm{mEq} / \mathrm{kg} / 24 \mathrm{~h}$ for one to two days depending on the adequacy of renal function and plasma potassium concentrations.

6. Magnesium should be administered post-operatively in a dosage of $1 \mathrm{mEq} /$ $\mathrm{kg} / 24 \mathrm{~h}$ for 24 hours.

\section{SUMMARY}

Acid-base and electrolyte changes are reported in 11 infants undergoing profound hypothermia for cardiac surgery by the technique of initial surface cooling followed by further bypass cooling and rewarming. Seven patients (group 1) underwent initial surface cooling to a mean oesophageal temperature of $26.6^{\circ} \mathrm{C}$ and four (group 2) to a mean oesophageal temperature of $32^{\circ} \mathrm{C}$.

During initial surface cooling, $\mathrm{PCO}_{2}$ was maintained close to $40 \mathrm{~mm} \mathrm{Hg}$ by 
the addition of $\mathrm{CO}_{2}$ to the inspired gas mixture and there were no significant mean changes in $\mathrm{pH}$ or calculated base excess values in either group. The most significant electrolyte change was the decrease in plasma $\mathrm{K}^{+}$in group 1 . The possible relationship between the decrease in plasma $\mathrm{K}^{+}$and the incidence of ventricular fibrillation was discussed. Although a slight but not statistically significant decrease in plasma total calcium was observed, the physiologically active ionic calcium level remained completely within the normal range. There were no changes in plasma $\mathrm{Na}^{+}$or magnesium during surface cooling in either group.

During bypass cooling any potential changes which might have resulted from the further drop in temperature were modified or overshadowed by the effects of the composition of the priming solution. Five per cent $\mathrm{CO}_{2}$ was found to be insufficient to maintain $\mathrm{PCO}_{2}$ levels during cooling bypass and at least 10 per cent $\mathrm{CO}_{2}$ is now recommended.

Administration of $\mathrm{NaHCO}_{3}$ to correct the metabolic acidosis observed early during bypass rewarming resulted in post-operative metabolic alkalosis. Correction of the acidosis was found to occur spontaneously by the time of chest closure, hence treatment is usually unnecessary.

Calcium ion activity is maintained during bypass and in the post-operative period by the addition of $2 \mathrm{ml}$ of 10 per cent $\mathrm{CaCl}_{2}$ to each unit of heparinized blood used in the prime or as replacement during bypass.

Plasma $\mathrm{K}^{+}$concentrations were normal during bypass cooling and early rewarming but decreased to low normal values by the time of chest closure. They remained low in both groups during the first 24 post-operative hours, half the values being in the hypokalaemic range despite the administration of potassium $(2 \mathrm{mEq} / \mathrm{kg} / 24 \mathrm{~h}$ ). The post-operative dosage of potassium in these infants should be increased to $3-4 \mathrm{mEq} / \mathrm{kg} / 24 \mathrm{~h}$ for 1 or 2 days depending on adequacy of renal function and plasma potassium levels.

The plasma magnesium concentrations were maintained in the normal range during bypass in both groups. Nevertheless, the patients in group 1 were hypomagnesaemic postoperatively.

A magnesium supplement administered postoperatively to the patients of group 2 in a dose of $1 \mathrm{mEq} / \mathrm{kg} / 24 \mathrm{~h}$ was sufficient to maintain plasma magnesium levels in the high normal range.

\section{RÉSUMÉ}

Nous avons fait l'étude des changements acide-base et électrolytiques chez 11 enfants soumis à une hypothermie profonde pour chirurgie cardiaque et, cela, avec la technique du refroidissement périphérique d'abord et, ensuite, d'un autre refroidissement par la circulation extracorporelle et puis, le réchauffement. Sept malades (groupe 1) ont subi un refroidissement périphérique de départ jusqu’à une température œsophagienne moyenne de $26.6^{\circ} \mathrm{C}$ et quatre autres malades (groupe 2) à une température œsophagienne moyenne de $32^{\circ} \mathrm{C}$.

Durant la phase initiale de refroidissement périphérique, nous avons maintenu la $\mathrm{PCO}_{2}$ près de $40 \mathrm{mmHg}$ en ajoutant du $\mathrm{CO}_{2}$ à l'air inspiré et nous n'avons pas observé de changement du $\mathrm{pH}$ ni de l'excès de base dans l'un et l'autre des 
groupes. Le changement le plus marqué a été celui de la diminution du potassium plasmatique dans le groupe 1 . Nous avons discuté le lien éventuel entre cette diminution du potassium plasmatique et la fréquence de la fibrillation ventriculaire. Bien que nous ayons observé une légère mais statistiquement non significative diminution du calcium total plasmatique, le taux de calcium ionisé et physiologiquement actif est demeuré dans les limites de la normale.

Le taux du sodium et du magnésium plasmatiques est demeuré inchangé durant le refroidissement périphérique dans les deux groupes.

Durant le refroidissement de la circulation extracorporelle, tous les changements éventuels qui auraient pu résulter d'une chute additionnelle de température étaient modifiés ou masqués par les effets de la solution d'amorce. Nous avons observé que 5 pour cent de $\mathrm{CO}_{2}$ n'était pas suffisant pour maintenir le taux de $\mathrm{CO}_{2}$ durant le refroidissement par la circulation extracorporelle et, maintenant, nous recommandons au moins 10 pour cent.

L'administration de bicarbonate de sodium pour corriger l'acidose remarquée précocement durant la circulation extracorporelle réchauffante a entrainé une alcalose métabolique au cours des suites opératoires. Nous avons noté que l'acidose se corrige spontanément durant la fermeture du thorax; le traitement devient alors superflu.

L'équilibre de l'ion calcium est surveillé durant la circulation extracorporelle et au cours des suites opératoires; nous ajoutons deux $\mathrm{ml} \mathrm{de} \mathrm{CaCl}_{2}$ à 10 pour cent chaque unité de sang hépariné utilisée pour l'amorce ou pour le traitement durant la circulation extracorporelle.

Les concentrations de potassium plasmatique sont demeurées normales durant la circulation extracorporelle de refroidissement et au début de réchauffement, mais elles ont diminué à des données normales basses au moment de la fermeture du thorax. Elles sont demeurées basses, pour les deux groupes, durant les premières 24 heures post opératoires; la moitié d'entre elles étant de l'ordre de l'hypo kalémie malgré l'administration de potassium ( $2 \mathrm{mEq} / \mathrm{Kg} / 24$ hres $)$. Nous conseillons d'augmenter le taux de potassium post-opératoire chez ces enfants à 3-4 $\mathrm{mEq} / \mathrm{Kg} / 24 \mathrm{~h}$ durant 1-2 jours selon le fonctionnement adéquat des reins et les taux de potassium plasmatique.

Nous avons maintenu l'équilibre des taux de magnésium plasmatique près de la normale durant la circulation extracorporelle dans les deux groupes. Néanmoins, au cours des suites opératoires, les malades du groupe 1 étaient hypomagnésiumhémiques.

Au cours des suites opératoires des malades du groupe 2, nous avons donné un supplément de magnésium à la dose de $1 \mathrm{mEq} / \mathrm{kg} / 24$ hres et cela a été suffisant pour maintenir les taux de magnésium plasmatique dans la partie haute de la normale.

\section{ACKNOWLEDGMENTS}

The authors acknowledge with gratitude the co-operation of William T. Mustard, M.D., F.R.C.S.(C), F.A.C.S., Associate Professor of Surgery, University of Toronto, Chief of Cardiovascular Surgery, The Hospital for Sick Children, To- 
ronto; and George Trusler, M.D., F.R.C.S.(C), F.A.C.S., Assistant Professor of Surgery, University of Toronto, Cardiovascular Surgeon, The Hospital for Sick Children; for allowing us to carry out these measurements on their patients.

The authors also acknowledge with gratitude the assistance and co-operation of Miss Patricia Morrison, R.N., Assistant O.R. Supervisor in charge of Cardiovascular Surgery and her Nursing Staff; and Mr. Jamie Villemater, R.N., in charge of the Extra-corporeal Circulation Unit; and the Nursing Staff in the Intensive Care Unit, The Hospital for Sick Children.

This work was supported in part by the Medical Research Council of Canada (Grant \#MA4386).

\section{REFERENCES}

1. Horiuchi, T., Koyamada, K., Matamo, I., et al. Radical operation for ventricular septal defect in infancy. J. Thorac. Cardiovasc. Surg. 46: 180 (1963).

2. Belsey, R.H.R., Dowlatshahi, K., Keen, G. Skinner, D.B. Profound hypothermia in cardiac surgery. J. Thorac. Cardiovasc. Surg. 56: 497-509 (1968).

3. Barretr-Boyes, B.G., Stmpson, M., \& Neutze, J.M. Intracardiac surgery in neonates and infants using deep hypothermia with surface cooling and limited cardiopulmonary,bypass. Circulation, Suppl. I to vols. 43 and 44: 125-130 (1971).

4. Seetye, E.R., Harris, E.A., SQuire, A.W., \& Barrett-Boyes, B.G. Metabolic effects of deep hypothermia and circulatory arrest in infants during cardiac surgery. Brit. J. Anaesth. 43: 449-459 (1971).

5. Steward, D.J., Johnston, A.E., \& SLOAN, I.A. Anaesthetic management of infants undergoing profound hypothermia for surgical correction of congenital heart defects. 21: 15-22 (1974). Can. Anaesth. Soc. J.

6. Jomston, A.E., RADDE, I.C., Nisbet, H.I.A., \& TAYLOR, J. Effects on divalent cations of a haemodilution technique using ACD blood in paediatric patients undergoing bypass open heart surgery. Can. Anaesth. Soc. J. 19: 498-516 (1972).

7. JohNSton, A.E., RADDE, I.C., NIsBet, H.I.A., \& TAYLOR, J. Effects of altering calcium in the haemodiluted pump primes on sodium and potassium in children undergoing open heart operations. Can. Anaesth. Soc. J. 19: 517-528 (1972).

8. Abrahams, N., Johnston, A.E., Taylor, J., Nisbet, H.I.A., \& Radde, I.C. A comparison of the effects of two haemodiluents on monovalent and divalent cations in children undergoing cardiopulmonary bypass and open heart surgery. Can. Anaesth. Soc. J. 20: 153-169 (1973).

9. Rosenthal, T.B. Effect of temperature on $\mathrm{pH}$ of blood and plasma in vitro. J. Biol. Chem. 173: 25-30 (1948).

10. Alcock, N., MacintYhe, I., \& Radde, I. The determination of magnesium in biological fluids and tissues by flame spectrophotometry. J. Clin. Pathol. 13: 506-510 (1960).

11. MacIntYre, I. Flame photometry. Adv. Clin. Chem. 4: 1-28 (1961).

12. Radde, I.C., Hoffken, B., Parkinson, D.K., Sheepers, J., \& Luckham, A. Practical aspects of a measurement technique for calcium ion activity in plasma. Clin. Chem. 17: 1002-1006 (1971).

13. Brown, M. E. Ultra-micro sugar determinations using 2,9-dimethyl-1-1,10-phenanthroline hydrochloride (Neocuproine). Diabetes 10:60-62 (1961).

14. Birtiner, D.L. \& MANNing, J. Automated neocuproine glucose method. Critical factors and normal values. In: Technico Symp. 1966, Automation in Analytical Chemistry. White Plains, N.Y., Mediad Inc., 1: 33 ( 1967 ).

15. Hunter, F.T., Grove-Rasmussen, M., \& Soutter, L. A spectrophotometric method for quantitating hemoglobin in plasma of serum. Am. J. Clin. Path. 20: 429-433.

16. Fairley, H.B. Metabolism in hypothermia. Br. Med. Bull, 17: 52-55 (1961).

17. NisBet, H.I.A. Acid-base disturbance in hypothermia. Int. Anesthesiol. Clin. 2: 829-855 (1964).

18. DundEE, J.W., \& CLAREE, R.S.J. Pharmacology of hypothermia. Int. Anesthesiol. Clin. 2: 857-872 (1964).

19. Litrie, D.M., Jв. Hypothermia. Anaesthesiol. 20: 842-877 (1959). 
20. NEIr, E. Electrolyte changes in hypothermia. Symp. on water and electrolyte metabolism (Amsterdam 1960). Ed. by C.P. Stewart and T.H. Strengers, Amsterdam, Elsevier Pub. Co. (1961).

21. Bunton, G.W. Metabolic acidosis during profound hypothermia. Anaesthesia 19: 365-375 (1964).

22. Callaghan, P.B., Lister, J., Paton, B.C., \& Swan, H. Effect of varying carbon-dioxide tensions on the oxyhaemoglobin dissociation curves under hypothermic conditions. Ann. Surg. 154: 903-910 (1961).

23. Wylie, W.D., \& Churchill-Davmson, H.C. A practice of Anaesthesia. 3rd ed., 12711297, 1972. Year Book Med. Pub. Inc., Chicago, Ill.

24. Brown, T.C.K., Clark, C.P., Shannahan, E.A., McKre, B.D., Wood, H.M., \& Thonp, E.A. The management of infants for cardiac surgery under deep hypothermia. Anaesth. and Intens. Care 1: 137-140 (1972).

25. Brown, T.C.K., Dunlop, M.E., Stevens, B.J., Clafke, C.P., \& Shannahan, E.A. Biochemical changes during surface cooling for deep hypothermia in open-heart surgery. J. Thorac. Cardiovasc. Surg. 65: 402-408 (1973).

26. Окамото, $Y$. Clinical studies for open heart surgery in infants with profound hypothermia. Arch. Jap. Chir. 38: 188-207 (1969).

27. Munday, K.A., Blane, G.F., Chin, E.F., \& Machell, E.S. Plasma electrolyte changes in hypothermia. Thorax 13: 334-342 (1958).

28. Wynn, V. Electrolyte disturbances associated with failure to metabolize glucose during hypothermia. Lancet 2: 575 (1954).

29. Reulen, H.J., Aignen, P., Brendel, W., \& Messmer, K. Elektrolytveränderungen in tiefer Hypothermie. Die Wirkung akutes Auskühlung bis $0^{\circ}$ C. und Wiedererwärmung. Pflügers Arch. 288: 197-219 (1966).

30. Baum, D., Dirlard, D.H., Morri, H., \& Crawford, E.W. Metabolic aspects of deep surgical hypothermia in infancy. Pediatrics 42: 93-105 (1968).

31. Baum, D., Dilland, D.H., \& Porte, D., Jr. Inhibition of insulin release in infants undergoing deep hypothermic cardio-vascular surgery. New Eng. J. Med. 279; 1309-1314 (1972).

32. Hewitt, R.L., Woo, R.D., Ryan, J.R., \& Drapanas, T. Plasma insulin and glucose relationships during cardiopulmonary bypass. Surgery 71: 905-912 (1972).

33. Hume, D.M., \& EGDAHL, R.H. Effect of hypothermia and of cold exposure on adrenal cortical and medullary secretions. Ann. N.Y. Acad. Sc. 80: 285 (1958).

34. MacPhee, I.W., Gray, T.C., \& Davies, S. Effect of hypothermia on adrenocortical response to operation. Lancet 2: 1196 ( 1958).

35. Gale, C.C., Jobin, M., Proppe, D.W., Notter, D., \& Fox, H. Endocrine thermoregulatory responses to local hypothalmic cooling in unanaesthetized baboons. Am. J. Physiol. 219: $193(1970)$

36. ToDd, E., Vick, R.L., \& TuRLIngton, J.T. The influence of epinephrine upon plasma potassium concentrations. Changes with time during constant infusion. Proc. Soc. Exp. Biol. Med. 128: 188 (1968).

37. Nowell, N.W. \& WhITE, D.C. Seasonal variation of magnesium and calcium in serum of the hypothermic rat. J. Appl. Physiol. 18: 967-969 (1963).

38. Pedersen, K.O. Binding of calcium to serum albumin. IV. Effect of temperature and thermodynamics of calcium-albumin-interaction. Scand. J. Clin. Lab. Invest. 30: 89 (1972).

39. Platner, W.S. \& Hosko, M.J. Mobility of serum magnesium in hypothermia. Am. J. Physiol. 174: 273-276 (1953).

40. Munday, K.A. \& Mary, B.W.J. Plasma electrolyte levels in a mammal and a reptile at various environmental temperatures. Proc. XXII Int. Physiol. Congr. 2: 492 (1962).

41. Burg, M.B. \& Orloff, J. Active transport by kidney tubules at $0^{\circ}$ C. Am. J. Physiol. 207: 983 (1964).

42. WALSER, M., RAHILL, W.J., \& RoBInson, B.H.B. Interdependence among cations in tubular reabsorption. Clin. Res. 11: 511 (1963).

43. MacRae, I.F., Kohler, H.F., \& Pechet, M.M. Interrelationship of $\mathrm{Mg}, \mathrm{Ca}$, and P metabolism. Clin. Res. 11: 223 (1963).

44. Putman, J.M. A routine method for determining plasma ionized calcium and its application to the study of congenital heart disease in children. Clin. Chim. Acta. 32: 33-41 (1972). 